\title{
Diastereoselective Synthesis of Tetrahydrofurans via Mead Reductive Cyclization of Keto- $\beta$-Lactones Derived from the Tandem Mukaiyama Aldol Lactonization (TMAL) Process
}

\author{
T. Andrew Mitchell and Daniel Romo* \\ Department of Chemistry, P.O. Box 30012, Texas A\&M University, College Station, TX 77842-3012
}

\begin{abstract}
The development of a diastereoselective, three-step strategy for the construction of substituted tetrahydrofurans from alkenyl aldehydes based on the tandem Mukaiyama aldol-lactonization process and Mead reductive cyclization of keto $\beta$-lactones is reported. Stereochemical outcomes of the TMAL process are consistent with models established for Lewis acid-mediated additions to $\alpha$ benzyloxy and $\beta$-silyloxy aldehydes while reductions of the five-membered oxocarbenium ions are consistent with Woerpel's models. Further rationalization for observed high diastereoselectivity in reductions of $\alpha$-silyloxy 5-membered oxocarbenium ions based on stereoelectronic effects are posited. A diagnostic trend for coupling constants of $\gamma$-benzyloxy $\beta$-lactones was observed that should enable assignment of the relative configuration of these systems.
\end{abstract}

\section{Introduction}

Tetrahydrofurans (THFs) are common heterocyclic motifs in natural products and thus many routes have been developed to access these moieties. ${ }^{1}$ These approaches can be divided into three major synthetic strategies (Figure 1). In one strategy, an oxygen nucleophile displaces, adds to, or opens an activated group $(\mathrm{G})$ such as a leaving group (e.g. mesylate), ${ }^{2}$ an olefin (e.g. iodoetherification), ${ }^{3}$ or a strained ring (e.g. epoxide $)^{4}$ to form a new C-O bond (Type I). In another strategy, a nucleophile adds to an oxocarbenium intermediate and a new $\mathrm{C}-\mathrm{C}$ or $\mathrm{C}-$ $\mathrm{H}$ bond is formed (Type II). ${ }^{5}$ Finally, several miscellaneous strategies have been developed ${ }^{1}$ including ring contractions of various six-membered rings such as tetrahydropyrans ${ }^{6}$ and $\delta$ lactones. ${ }^{7}$

Some of the most elegant and efficient approaches to THFs fall into the last category (Type III). Overman developed the Prins-pinacol route to THFs 8 that has been applied to transkumausyne and other members of the Laurencia family of marine natural products, ${ }^{9}$ as well as (-)-citreoviral ${ }^{10}$ and briarellin E. ${ }^{11}$ Roush and Micalizio ${ }^{12}$ refined and expanded the $[3+2]$ annulation of aldehydes and allylsilanes toward THFs first reported by Panek. ${ }^{13}$ This strategy had been applied to pectenotoxin II, ${ }^{14}$ amphidinolide F, ${ }^{15}$ asimicin, ${ }^{16}{ }_{(+) \text {-bullatacin, }}{ }^{17}$ angelmicin $\mathrm{B},{ }^{18}$ and haterumalide ND. ${ }^{19}$ Lee developed a radical cyclization approach to $\mathrm{THFs}^{20}$ and utilized this method in the total synthesis of pamamycin $607,,^{21}(+)$-methyl nonactate, ${ }^{22}$ kumausallene, ${ }^{23}$ and kumausyne. ${ }^{24}$ Herein, we report a hybrid of Type I and Type II strategies that involves a Mead reductive cyclization of keto- $\beta$-lactones prepared by the tandem Mukaiyama aldol-lactonization (TMAL) process. 
$\beta$-Lactones continue to gain prominence as versatile intermediates in synthesis, 25 to be found as integral components in bioactive natural products, ${ }^{26}$ and to demonstrate utility as enzyme inhibitors with therapeutic potential. ${ }^{27}$ We previously reported stereoselective routes to both cis $^{28}$ and trans ${ }^{29} \beta$-lactones via tandem Mukaiyama aldol-lactonization (TMAL) processes employing substrate control (Scheme 1). ${ }^{28,29}$ This methodology was applied to total syntheses of (-)-panclicin $\mathrm{D}, 27 \mathrm{a}$ tetrahydrolipstatin/orlistat, $27 \mathrm{~b}$ okinonellin B, ${ }^{27 \mathrm{c}}$ and brefeldin A.

$27 \mathrm{~d}$ Mead previously demonstrated the utility of simple keto- $\beta$-lactones $\mathbf{8}$ for the synthesis of THFs 9 by a Lewis acid mediated, reductive cyclization process (Scheme 2). ${ }^{30}$ Building on these precedents, we envisioned a highly diastereoselective synthesis of substituted tetrahydrofurans by combining the TMAL process and Mead reductive cyclization of substituted keto- $\beta$-lactones (Scheme 3).

\section{Results and Discussion}

\section{Synthesis of Keto- $\beta$-Lactones 12a-f via the Tandem Mukaiyama Aldol Lactonization}

The required aldehydes $( \pm)-\mathbf{1 0 a}-\mathbf{c}$, possessing both $\alpha$ - and $\beta$-oxygenation, were prepared in racemic fashion by standard procedures (Scheme 4). ${ }^{31}$ Application of the TMAL process to $\alpha$-benzyloxy aldehyde $( \pm)$-10a employing propionate ketene acetal 6a proceeded with high diastereoselectivity to give $\beta$-lactone 11a based on chelation control (Table 1, entry 1). However, acetate ketene acetal $\mathbf{6 b}$ gave low diastereoselectivity as expected with only a slight preference for the Felkin-Ahn derived $\beta$-lactone anti-11b (Table 1, entry 2). It is worth noting that both of these TMAL reactions proceeded in comparable yield and diastereoselectivity at $0^{\circ} \mathrm{C}$ under slightly prolonged reaction times. The sterically demanding, oxygenated ketene acetal $\mathbf{6 c}$ delivered moderate yield of anti-11c after prolonged reaction times and proceeded with moderate diastereoselectivity (Table 1 , entry 3 ). In the case of $\beta$-silyloxy aldehydes $( \pm)$-10b-c, $\beta$-lactones 11d-f were obtained with moderate diastereoselectivity and the stereochemical outcome is consistent with Evans' model ${ }^{32}$ and our previous studies 27 (Table 1, entries 4 and 6). Once again, acetate ketene acetal $\mathbf{6 b}$ gave low diastereoselectivity as expected (Table 1, entry 5). Our previous studies suggested that use of thiophenyl acetate ketene acetal 18 with $\alpha$-benzyloxy aldehyde $( \pm)$-10a may lead to a reversal of selectivity toward the chelation controlled adduct, which could be attributed to greater possibility for chelation control due to the monodentate thiophenyl ligand. ${ }^{33}$ Indeed, this reversal was observed for $\alpha$ unsubstituted- $\beta$-lactones $\mathbf{1 1 b}$, albeit in diminished ratio (Scheme 5).

Ozonolysis of alkenyl- $\beta$-lactones $\mathbf{1 1}$ proceeded smoothly to deliver the required keto- $\beta$ lactones 12 for reductive cyclization (Scheme 6). The use of $\mathrm{PPh}_{3}$ to reduce the ozonides proved to be more efficient leading to fewer by-products compared to dimethyl sulfide and therefore simplified purification. Due to some instability noted for keto- $\beta$-lactones $\mathbf{1 2}$, they were typically rapidly purified and used immediately in subsequent Mead reductive cyclizations.

\section{Stereochemical Assignment of $\beta$-Lactones 11-12}

With the exception of $\beta$-lactones 11c, bearing a bulky TBDPS group, stereochemical assignment of $\beta$-lactones 11a-f obtained via the TMAL process corresponded to previous reports and were subsequently confirmed by nOe analysis of the corresponding THFs $\mathbf{1 3 a}-\mathbf{f}$ (vide infra). ${ }^{31}$ However, the $\gamma$-benzyloxy- $\beta$-lactones $11 \mathbf{a}-\mathbf{c}$ and $12 \mathbf{a}-\mathbf{c}$ displayed a significant trend in coupling constants that may be a predictive tool for assignment of relative (i.e. syn vs. anti) stereochemistry of these systems (Table 2). It is well established that the internal stereochemistry (i.e. cis vs. trans) of $\beta$-lactones can be assigned based on coupling constant analysis and this is observed for $\beta$-lactones 11-12 (cis: $J_{3,4}=5.7-6.0 \mathrm{~Hz}$; trans: $J_{3,4}=3.3-4.5$ $\mathrm{Hz}) .{ }^{34}$ However, to the best of our knowledge, the determination of relative stereochemistry of these systems has not previously been based solely on coupling constant analysis. In the case of $\gamma$-benzyloxy- $\beta$-lactones $11 a-c$ and 12a-c, the coupling constants for $\operatorname{syn}\left(J_{4,5}=4.5-\right.$ 
$6.0 \mathrm{~Hz})$ and anti $\left(J_{4,5}=2.7-3.6 \mathrm{~Hz}\right)$ diastereomers followed a clear trend that is also consistent with our previous studies. ${ }^{27}$ This is likely due to the conformational rigidity of these systems resulting from torsional strain. ${ }^{35}$ Although subsequent nOe data for the direct stereochemical assignment of THF 13c was inconclusive, a tentative assignment of the precursor $\beta$-lactones anti-11c and anti-12c based on this diagnostic coupling constant trend is plausible.

\section{Optimization of Mead Reductive Cyclization}

Initial studies of the reductive cyclization of keto- $\beta$-lactone syn-12a employing conditions reported by Mead with $\mathrm{TiCl}_{4}$ or $\mathrm{BF}_{3} \bullet \mathrm{OEt}_{2}$ as Lewis acid led to the desired THF 13a along with significant quantities of an unexpected by-product, furan 19 (Table 3, entries 1-2). Mead found that silyl triflates also promoted cyclization of keto $\beta$-lactones to THFs. ${ }^{36}$ When triethylsilyl triflate (TESOTf) was added dropwise at $-78{ }^{\circ} \mathrm{C}$ and then warmed quickly to $0{ }^{\circ} \mathrm{C}$, the ratio of THF to furan did not improve significantly, but this provided the desired THF 13a as the major product (Table 3, entry 3). After extensive experimentation, we found that when TESOTf was added down the side of the flask at $-78{ }^{\circ} \mathrm{C}$ ("pre-cooled") as a dilute solution in $\mathrm{CH}_{2} \mathrm{Cl}_{2}$ and the reaction was allowed to warm to $0{ }^{\circ} \mathrm{C}$ slowly over $6 \mathrm{~h}$, this provided the desired THF 13a in $62 \%$ yield with only $6 \%$ of furan 19 (Table 3, entry 4). Further improvements resulted when a large excess of $\mathrm{Et}_{3} \mathrm{SiH}$ (20.0 equiv) was employed and THF 13a was isolated in $67 \%$ yield as a single diastereomer with only trace amounts of furan $\mathbf{1 9}$ (Table 3, entry 5). Finally, a control experiment revealed that furan 19 was the only product formed in the absence of $\mathrm{Et}_{3} \mathrm{SiH}$ (Table 3, entry 6). Indeed, furan by-products have been observed previously during reductions of 5-membered oxocarbenium ions. 37

\section{Scope of Mead Reductive Cyclization}

Using the optimized conditions, various $\gamma$-benzyloxy-keto- $\beta$-lactones 12 were converted to THFs 13 with efficient transfer of stereochemistry and only trace quantities of furan were observed (Table 4, entries 1-2). It is interesting to note that a possible stereoreinforcing effect is operative with anti- and syn- $\beta$-lactones $\mathbf{1 2 b}$ (dr, 14:1 vs 19:1, respectively) which may be due to a developing 1,3-diaxial interaction of the oxocarbenium intermediate ( $c f$. 24 , Scheme 7) leading to greater selectivity for "inside attack." In the case of keto- $\beta$-lactone 12c, TESOTf delivered a complex mixture of products, while $\mathrm{BF}_{3} \cdot \mathrm{OEt}_{2}$ provided a cleaner, albeit slower reaction to provide THF $\mathbf{1 3 c}$ (Table 4 , entry 3 ). In the case of $\delta$-silyloxy-keto- $\beta$-lactones $\mathbf{1 2 d -}$ f, there was less concern of furan formation based on our proposed mechanism (vide infra). Thus, the strong Lewis acid $\mathrm{TiCl}_{4}$ previously utilized by Mead promoted the reductive cyclization in moderate to good yields with excellent levels of stereochemical transfer using only 1.2 equivalents of $\mathrm{Et}_{3} \mathrm{SiH}$ (Table 4, entries 4-6). The relative stereochemistry of all ring stereocenters of THFs 13a-f was confirmed by nOe analysis observed for multiple protons of the THF rings, ${ }^{31}$ which also confirmed invertive ring cleavage during cyclization. The relative stereochemistry between the $\alpha$-stereocenter and the THF rings is premised on stereochemical invertive cyclization of the trans-substituted (vs. cis) $\beta$-lactones, which in turn is based on coupling constants. An exception was THF 13c for which nOe data were inconclusive and thus relative stereochemistry was tentatively assigned based on coupling constants ( $c f$. Table 2). Thus, the stereochemical outcome in each case is consistent with stereochemical invertive alkyl $\mathrm{C}-\mathrm{O}$ ring cleavage by the pendant ketone followed by reduction of the oxocarbenium to the tetrahydrofuran as predicted by the Woerpel model. 38

\section{Mechanistic Rationale for Mead Reductive Cyclization}

Regarding the mechanism of this process for benzyloxy-substituted systems, the reductive cyclization leading to THF 20 and furan 21 is presented as an example (Scheme 7). Ketone cleavage of a silyl activated $\beta$-lactone intermediate 22 via alkyl C-O scission in an $\mathrm{S}_{\mathrm{N}} 2$ fashion delivers the oxocarbenium $\mathbf{2 3}$ in line with previous proposals by Mead. ${ }^{30}$ The 
stereoelectronically favored envelope conformation $\mathbf{2 4}$ places the benzyloxy substituent in the pseudoaxial orientation as proposed by Woerpel and reduction occurs via "inside attack" of $\mathrm{Et}_{3} \mathrm{SiH}^{38}$ Alternatively, a competing pathway leading to furan $\mathbf{2 1}$ could involve elimination leading to enol ether $\mathbf{2 5}$ which then undergoes acid-mediated elimination of benzyl alcohol to provide oxocarbenium 26. This is followed by rapid aromatization to furan $\mathbf{2 1}$ by loss of a second proton, which may occur upon reaction work-up.

In the case of $\delta$-silyloxy-keto- $\beta$-lactones $\mathbf{1 2 d} \mathbf{d} \mathbf{- f}$, based on Woerpel's findings with related benzyloxy systems which provided diastereomeric ratios of 5-6:1, we expected only moderate selectivity for the reduction of oxocarbeniums $\mathbf{2 8}$ (Scheme 8). ${ }^{38 \mathrm{~b}}$ However, we found that the diastereoselectivity of the reduction was $>19: 1$ since the diastereomeric ratio of the THFs $\mathbf{1 3 d}-$ $\mathbf{f}$ matched well with the diastereomeric ratio of the substrate $\beta$-lactones $\mathbf{1 2 d} \mathbf{d} \mathbf{- f}$, respectively. There appear to be several factors governing this increase in selectivity. Woerpel has shown that hydrogen atoms prefer to reside in the pseudoaxial position adjacent to an oxocarbenium in both five and six-membered rings for favorable hyperconjugation between the $\mathrm{C}$ - $\mathrm{H}$ bond and the $2 p$ orbital of the oxocarbenium. ${ }^{38 b, 39}$ Less studied by Woerpel were the effects of $\alpha$ silyloxy oxocarbeniums and both steric and electronic effects could influence the stereochemical outcome. The decreased electron density of the oxygen due to the silyloxy moiety ${ }^{40}$ leads to lower electron donation compared to a benzyloxy substituent. Thus, compared to the hydrogen atom, the pseudequatorial orientation of the silyloxy substituent is preferred to a greater extent. Steric considerations would also dictate that the more bulky silyloxy group reside in the pseudoequatorial position to a greater degree than a benzyloxy substituent. Additionally, developing gauche interactions between the C5 methyl and the pseudoequatorial silyloxy substituent also favors "inside attack" of $\mathrm{Et}_{3} \mathrm{SiH}$ ( $c f$. 28 , Scheme 8). These effects combine with the preferred "inside attack" leading to high diastereoselectivity for $\alpha$-silyloxy substituted-oxocarbenium ions.

In summary, we developed a three-step strategy for the diastereoselective synthesis of THFs from alkenyl aldehydes proceeding through $\beta$-lactone intermediates. The strategy involves the TMAL process and Mead's reductive cyclization of keto- $\beta$-lactones. The stereoselectivity of the latter process is rationalized by Woerpel's model for "inside attack" of oxocarbeniums. An increase in selectivity for certain $\alpha$-silyloxy oxocarbenium ions was observed and is rationalized based on stereoelectronic effects building on Woerpel's findings. The stereoselectivity of the TMAL process for $\alpha$-benzyloxy and $\beta$-silyloxy aldehydes with several thiopyridyl ketene acetals was defined including a reversal in selectivity when a thiophenyl ketene acetal was employed. A correlation between relative stereochemistry and coupling constants was observed that provides a predictive method for the stereochemical assignment of $\gamma$-benzyloxy- $\beta$-lactones. This strategy should prove useful for the synthesis of tetrahydrofurans found in natural products and the results of these studies will be reported in due course.

\section{Experimental Section}

\section{Representative procedure for the TMAL reaction as described for $\gamma$-benzyloxy-alkenyl- $\beta$ - lactone syn-11a}

$\mathrm{ZnCl}_{2}(273 \mathrm{mg}, 2.00 \mathrm{mmol}$ ) was freshly fused at $\sim 0.5 \mathrm{~mm} \mathrm{Hg}$ and subsequently cooled to ambient temperature. Ketene acetal $\mathbf{6 a}(384 \mathrm{mg}, 1.20 \mathrm{mmol})$ and then aldehyde ( \pm )-10a (204 $\mathrm{mg}, 1.00 \mathrm{mmol}$ ) were each added as a solution in $5 \mathrm{~mL}$ of $\mathrm{CH}_{2} \mathrm{Cl}_{2}$ (final concentration of aldehyde in $\mathrm{CH}_{2} \mathrm{Cl}_{2} \sim 0.1 \mathrm{M}$ ). This suspension was stirred for $14 \mathrm{~h}$ at $23^{\circ} \mathrm{C}$ then quenched with $\mathrm{pH} 7$ buffer, stirred vigorously for $30 \mathrm{~min}$, and poured over Celite with additional $\mathrm{CH}_{2} \mathrm{Cl}_{2}$. After concentration under reduced pressure, the residue was redissolved in $\mathrm{CH}_{2} \mathrm{Cl}_{2}$ (final concentration of $\beta$-lactone in $\mathrm{CH}_{2} \mathrm{Cl}_{2} \sim 0.15 \mathrm{M}$ ) and treated with $\mathrm{CuBr}_{2}(357 \mathrm{mg}, 1.60 \mathrm{mmol}$ ). After stirring for $2.5 \mathrm{~h}$, the crude $\beta$-lactone syn-11a was again poured over Celite and washed 
with ether $(200 \mathrm{~mL})$. The combined organic layers were washed with $10 \%$ aq. $\mathrm{K}_{2} \mathrm{CO}_{3}(3 \times 50$ $\mathrm{mL}), \mathrm{H}_{2} \mathrm{O}(2 \times 50 \mathrm{~mL})$, and brine $(2 \times 50 \mathrm{~mL})$, dried over $\mathrm{MgSO}_{4}$, filtered, and concentrated under reduced pressure to deliver crude $\beta$-lactone syn-11a as a single diastereomer (>19:1) as judged by analysis of crude ${ }^{1} \mathrm{H}$ NMR $(300 \mathrm{MHz})$. Purification by flash column chromatography (hexanes:ethyl acetate 95:5) delivered pure $s y n-11 a(216 \mathrm{mg}, 83 \%)$ as a colorless oil: $\mathrm{R}_{f}=0.42$ (80:20 hexanes:ethyl acetate); IR (thin film) 3071, 3031, 1827, $1119 \mathrm{~cm}^{-1} ;{ }^{1} \mathrm{H}$ NMR (300 $\left.\mathrm{MHz}, \mathrm{CDCl}_{3}\right) \delta 1.38(\mathrm{~d}, J=7.5 \mathrm{~Hz}, 3 \mathrm{H}), 1.78(\mathrm{dd}, J=0.9,1.2 \mathrm{~Hz}, 3 \mathrm{H}), 2.25(\mathrm{ddd}, J=0.9,6.3$, $14.1 \mathrm{~Hz}, 1 \mathrm{H}), 2.40$ (ddd, $J=1.2,6.9,14.1 \mathrm{~Hz}, 1 \mathrm{H}), 3.43(\mathrm{dq}, J=4.2,7.5 \mathrm{~Hz}, 1 \mathrm{H}), 3.74$ (ddd, $J=6.0,6.3,6.9 \mathrm{~Hz}, 1 \mathrm{H}), 4.22(\mathrm{dd}, J=4.2,6.0 \mathrm{~Hz}, 1 \mathrm{H}), 4.66(\mathrm{~d}, J=12.0 \mathrm{~Hz}, 1 \mathrm{H}), 4.70(\mathrm{~d}, J$ $=12.0 \mathrm{~Hz}, 1 \mathrm{H}), 4.83-4.86(\mathrm{~m}, 1 \mathrm{H}), 4.88-4.91(\mathrm{~m}, 1 \mathrm{H}), 7.29-7.37(\mathrm{~m}, 5 \mathrm{H}) ;{ }^{13} \mathrm{C} \mathrm{NMR}(75 \mathrm{MHz}$, $\left.\mathrm{CDCl}_{3}\right) \delta 12.2,22.7,38.7,47.5,72.5,76.8,80.5,114.2,127.78,127.82(2), 128.4(2), 137.9$, 140.9, 171.5; ESI-HRMS Calcd for $\mathrm{C}_{16} \mathrm{H}_{20} \mathrm{O}_{3} \mathrm{Li}[\mathrm{M}+\mathrm{Li}]$ 267.1572, found 267.1591.

\section{Representative procedure for Mead reductive cyclization of $\gamma$-benzyloxy-keto- $\beta$-lactones as described for THF 13a (Procedure A)}

To a solution of $\gamma$-benzyloxy-keto- $\beta$-lactone syn-12a (262 mg, $1.00 \mathrm{mmol})$ in $\mathrm{CH}_{2} \mathrm{Cl}_{2}(50 \mathrm{~mL})$ was added $\mathrm{Et}_{3} \mathrm{SiH}(3.2 \mathrm{~mL}, 20.0 \mathrm{mmol})$ slowly at $-78^{\circ} \mathrm{C}$ followed by TESOTf $(274 \mu \mathrm{L}, 1.20$ mmol in $40 \mathrm{~mL} \mathrm{CH}_{2} \mathrm{Cl}_{2}$ ) down the side of the flask at $-78{ }^{\circ} \mathrm{C}$ over $10 \mathrm{~min}$ to ensure cooling. Upon addition of $10 \mathrm{~mL}$ of $\mathrm{CH}_{2} \mathrm{Cl}_{2}$ to rinse down any remaining TESOTf, the solution was allowed to warm to $0{ }^{\circ} \mathrm{C}$ slowly over $5 \mathrm{~h}$, quenched with $\mathrm{pH} 4$ buffer $(50 \mathrm{~mL})$, and warmed to $23{ }^{\circ} \mathrm{C}$ with vigorous stirring. The layers were separated and the aqueous layer was extracted with $\mathrm{CH}_{2} \mathrm{Cl}_{2}(3 \times 50 \mathrm{~mL})$. The combined organic extracts were dried over $\mathrm{MgSO}_{4}$, filtered, and concentrated under reduced pressure to deliver crude THF 13a as a single diastereomer (>19:1) with only trace amounts of furan 19 (68:1) as judged by analysis of crude ${ }^{1} \mathrm{H}$ NMR (500 MHz). Gradient flash column chromatography (hexanes:ethyl acetate 80:20 to 60:40) delivered THF 13a (178 mg, 67\%) as a colorless oil. A center fraction from the column was used for characterization: $\mathrm{R}_{f}=0.46$ (60:40 hexanes:ethyl acetate); IR (thin film) 3500-2300, $1708,1091 \mathrm{~cm}^{-1} ;{ }^{1} \mathrm{H}$ NMR $\left(500 \mathrm{MHz}, \mathrm{CDCl}_{3}\right) \delta 1.23(\mathrm{~d}, J=7.0 \mathrm{~Hz}, 3 \mathrm{H}), 1.29(\mathrm{~d}, J=6.0 \mathrm{~Hz}$, $3 \mathrm{H}), 1.54$ (ddd, $J=6.5,10.5,13.5 \mathrm{~Hz}, 1 \mathrm{H}), 2.11(\mathrm{ddd}, J=1.0,5.0,13.5 \mathrm{~Hz}, 1 \mathrm{H}), 2.68(\mathrm{dq}, J$ $=6.0,7.0 \mathrm{~Hz}, 1 \mathrm{H}), 4.01(\mathrm{ddd}, J=1.0,3.0,6.5 \mathrm{~Hz}, 1 \mathrm{H}), 4.12(\mathrm{dd}, J=3.0,6.0 \mathrm{~Hz}, 1 \mathrm{H}), 4.21-$ $4.28(\mathrm{~m}, 1 \mathrm{H}), 4.49(\mathrm{~d}, J=11.5 \mathrm{~Hz}, 1 \mathrm{H}), 4.52(\mathrm{~d}, J=11.5 \mathrm{~Hz}, 1 \mathrm{H}), 7.27-7.37(\mathrm{~m}, 5 \mathrm{H}) ;{ }^{13} \mathrm{C}$ NMR $\left(125 \mathrm{MHz}, \mathrm{CDCl}_{3}\right) \delta 12.8,20.5,40.1,42.8,71.4,75.3,81.9,85.4,127.88(2), 127.95$, 128.6(2), 138.1, 178.7; ESI-HRMS calcd for $\mathrm{C}_{15} \mathrm{H}_{19} \mathrm{O}_{4}$ [M - H] 263.1283, found 263.1271.

\section{Representative procedure for Mead reductive cyclization of $\gamma$-benzyloxy-keto- $\beta$-lactones as described for THF 13c (Procedure B)}

To a solution of $\gamma$-benzyloxy-keto- $\beta$-lactone $12 \mathrm{c}(199 \mathrm{mg}, 0.40 \mathrm{mmol})$ in $\mathrm{CH}_{2} \mathrm{Cl}_{2}(20 \mathrm{~mL})$ was added $\mathrm{Et}_{3} \mathrm{SiH}(1.3 \mathrm{~mL}, 8.00 \mathrm{mmol})$ slowly at $-78^{\circ} \mathrm{C}$ followed by $\mathrm{BF}_{3} \cdot \mathrm{OEt}_{2}(61 \mu \mathrm{L}, 0.48 \mathrm{mmol}$ in $16 \mathrm{~mL} \mathrm{CH}_{2} \mathrm{Cl}_{2}$ ) down the side of the flask at $-78{ }^{\circ} \mathrm{C}$ over $10 \mathrm{~min}$ to ensure cooling. Upon addition of $10 \mathrm{~mL}$ of $\mathrm{CH}_{2} \mathrm{Cl}_{2}$ to rinse down any remaining $\mathrm{BF}_{3} \cdot \mathrm{OEt}_{2}$, the solution was allowed to warm to $0{ }^{\circ} \mathrm{C}$ slowly over $5 \mathrm{~h}$, and then stirred at $0-10{ }^{\circ} \mathrm{C}$ for $3 \mathrm{~d}$. The reaction was quenched with $\mathrm{pH} 4$ buffer $(50 \mathrm{~mL})$, and warmed to $23^{\circ} \mathrm{C}$ with vigorous stirring. The layers were separated and the aqueous layer was extracted with $\mathrm{CH}_{2} \mathrm{Cl}_{2}(3 \times 50 \mathrm{~mL})$. The combined organic extracts were dried over $\mathrm{MgSO}_{4}$, filtered, concentrated under reduced pressure to deliver crude THF 13c as a mixture of diastereomers ( 18:1, 50\% conversion) as judged by analysis of crude ${ }^{1} \mathrm{H}$ NMR (500 MHz). Gradient flash column chromatography (hexanes:ethyl acetate 90:10 to 60:40) delivered recovered $\mathbf{1 2 c}(70 \mathrm{mg}, 35 \%$, dr 18:1) as a pale yellow oil and THF 13c $(102 \mathrm{mg}, 51 \%$, dr 18:1) as a pale yellow oil. A center fraction of THF 13c from the column was used for characterization. Characterization data for the major (anti) diastereomer 13c: $\mathrm{R}_{f}$ $=0.30$ (70:30 hexanes:ethyl acetate); IR (thin film) 3437-2404, 1731, $1108 \mathrm{~cm}^{-1} ;{ }^{1} \mathrm{H}$ NMR $\left(500 \mathrm{MHz}, \mathrm{CDCl}_{3}\right) \delta 1.12(\mathrm{~s}, 9 \mathrm{H}), 1.27(\mathrm{~d}, J=6.0 \mathrm{~Hz}, 3 \mathrm{H}), 1.48(\mathrm{ddd}, J=6.5,11.0,13.5 \mathrm{~Hz}$, $1 \mathrm{H}), 2.03(\mathrm{dd}, J=5.0,13.5 \mathrm{~Hz}, 1 \mathrm{H}), 4.07(\mathrm{dd}, J=2.5,6.5 \mathrm{~Hz}, 1 \mathrm{H}), 4.16(\mathrm{dd}, J=2.5,4.5 \mathrm{~Hz}$, 
$1 \mathrm{H}), 4.18-4.24(\mathrm{~m}, 1 \mathrm{H}), 4.32(\mathrm{~s}, 2 \mathrm{H}), 4.43(\mathrm{~d}, J=4.5 \mathrm{~Hz}, 1 \mathrm{H}), 7.23-7.70(\mathrm{~m}, 15 \mathrm{H}) ;{ }^{13} \mathrm{C} \mathrm{NMR}$ $\left(125 \mathrm{MHz} \mathrm{CDCl}_{3}\right) \delta 19.7,20.0,27.2(3), 40.3,71.5,72.8,75.8,81.0,86.1,127.8(2), 127.9$, 128.00(2), 128.04(2), 128.6(2), 130.36, 130.40, 132.3, 132.8, 136.0(2), 136.2(2), 138.1, 173.0; ESI-HRMS calcd for $\mathrm{C}_{30} \mathrm{H}_{35} \mathrm{O}_{5} \mathrm{Si}[\mathrm{M}-\mathrm{H}]$ 503.2254, found 503.2241.

\section{Representative procedure for Mead reductive cyclization of $\delta$-silyloxy-keto- $\beta$-lactones as described for THF 13d (Procedure C)}

To a solution of $\delta$-silyloxy-keto- $\beta$-lactone $12 \mathbf{d}(202 \mathrm{mg}, 0.71 \mathrm{mmol})$ in $\mathrm{CH}_{2} \mathrm{Cl}_{2}(15 \mathrm{~mL})$ was added $\mathrm{Et}_{3} \mathrm{SiH}(137 \mu \mathrm{L}, 0.85 \mathrm{mmol})$ dropwise at $-78{ }^{\circ} \mathrm{C}$ followed by $\mathrm{TiCl}_{4}(846 \mu \mathrm{L}, 1.0 \mathrm{M}$ in $\mathrm{CH}_{2} \mathrm{Cl}_{2}$ ) down the side of the flask at $-78{ }^{\circ} \mathrm{C}$ over $5 \mathrm{~min}$ to ensure cooling. Upon addition of $5 \mathrm{~mL}$ of $\mathrm{CH}_{2} \mathrm{Cl}_{2}$ to rinse down any remaining $\mathrm{TiCl}_{4}$, the solution was stirred at $-78{ }^{\circ} \mathrm{C}$ for 3 $\mathrm{h}$, quenched with $\mathrm{pH} 7$ buffer $(50 \mathrm{~mL})$, and warmed to $23{ }^{\circ} \mathrm{C}$ with vigorous stirring. The layers were separated and the aqueous layer was extracted with $\mathrm{CH}_{2} \mathrm{Cl}_{2}(3 \times 50 \mathrm{~mL})$. The combined organic extracts were dried over $\mathrm{MgSO}_{4}$, filtered, concentrated under reduced pressure to deliver crude THF 13d as a mixture of diastereomers (9:1) as judged by analysis of crude ${ }^{1} \mathrm{H}$ NMR (500 MHz). Gradient flash column chromatography (hexanes:ethyl acetate 90:10 to 60:40) delivered THF 13d (170 mg, 84\%, dr 9:1) as a pale yellow oil: Characterization data for the major (syn) diastereomer 13d: $\mathrm{R}_{f} 0.49$ (hexanes:ethyl acetate 60:40); IR (thin film) 3475-2460, 1707, $1250 \mathrm{~cm}^{-1} ;{ }^{1} \mathrm{H}$ NMR (500 MHz, $\left.\mathrm{C}_{6} \mathrm{D}_{6}\right) \delta-0.04$ (s, 6H), 0.90 (s, 9H), 1.07 $(\mathrm{d}, J=6.5 \mathrm{~Hz}, 3 \mathrm{H}), 1.14(\mathrm{~d}, J=7.0 \mathrm{~Hz}, 3 \mathrm{H}), 1.74$ (ddd, $J=6.5,8.5,13.0 \mathrm{~Hz}, 1 \mathrm{H}), 1.78$ (ddd, $J=3.5,6.5,13.0 \mathrm{~Hz}, 1 \mathrm{H}), 2.47(\mathrm{dq}, J=7.0,7.0 \mathrm{~Hz}, 1 \mathrm{H}), 3.67$ (ddd, $J=3.5,4.0,6.5 \mathrm{~Hz}, 1 \mathrm{H})$, $3.79(\mathrm{dq}, J=4.0,6.51 \mathrm{H}), 4.24(\mathrm{ddd}, J=3.5,7.0,8.5 \mathrm{~Hz}, 1 \mathrm{H}) ;{ }^{13} \mathrm{C} \mathrm{NMR}\left(125 \mathrm{MHz}, \mathrm{C}_{6} \mathrm{D}_{6}\right) \delta$ $-4.8,-4.6,13.3,18.1,19.1,25.9(3), 39.0,45.0,78.3,78.7,82.5,180.6$; ESI-HRMS calcd for $\mathrm{C}_{14} \mathrm{H}_{27} \mathrm{O}_{4} \mathrm{Si}[\mathrm{M}-\mathrm{H}] 287.1679$, found 287.1611.

\section{Supplementary Material}

Refer to Web version on PubMed Central for supplementary material.

\section{Acknowledgment}

We thank the NIH (GM-069784) and the Welch Foundation (A-1280) for generous support of this work. We thank Dr. Ziad Moussa (TAMU) for helpful discussions and Dr. Shane Tichy of the Laboratory for Biological Mass Spectrometry supported by the Office of the Vice President for Research (TAMU) for acquiring mass spectral data and helpful discussions.

\section{References}

1. For reviews on the synthesis of THFs, see(a) Kang JE, Lee E. Chem. Rev 2005;105:4348. [PubMed: 16351047] (b) Norcross R, Paterson I. Chem. Rev 1995;95:2041. (c) Harmange J-C, Figadere B. Tetrahedron: Asymmetry 1993;4:1711. (d) Boivin T. Tetrahedron 1987;43:3309.

2. (a) Buchanan JG, Dunn AD, Edgar AR. J. Chem. Soc., Perkin 1974;1:1943. (b) Buchanan JG, Dunn AD, Edgar AR. J. Chem. Soc., Perkin 1975;1:1191.

3. Rychnovsky SD, Bartlett PA. J. Am. Chem. Soc 1981;103:3963.

4. Chamberlin previously reported a similar route to THFs as Mead, but utilizing epoxides instead of $\beta$ lactones(a) Mulholland RL, Chamberlin AR. J. Org. Chem 1988;53:1082. (b) Fotsh CH, Chamberlin AR. J. Org. Chem 1991;56:4141.

5. Ogawa T, Pernet AG, Hanessian S. Tetrahedron Lett 1973;37:3543.

6. Michael P, Ting PC, Bartlett PA. J. Org. Chem 1985;50:2416.

7. Mantell SJ, Ford PS, Watkin DJ, Fleet GWJ, Brown D. Tetrahedron Lett 1992;33:4503.

8. For initial disclosure, seeHopkins MH, Overman LE. J. Am. Chem. Soc 1987;109:4748.For a Perspective, seePennington LD, Overman LE. J. Org. Chem 2003;68:7143. [PubMed: 12968864] 
9. (a) Brown MJ, Harrison T, Overman LE. J. Am. Chem. Soc 1991;113:5378. (b) Grese TA, Hutchinson KD, Overman LE. J. Org. Chem 1993;58:2468.

10. Hanaki N, Link JT, MacMillan DWC, Overman LE, Trankle WG, Wurster JA. Org. Lett 2000;2:223. [PubMed: 10814287]

11. Corminboeuf O, Overman LE, Pennington LD. J. Am. Chem. Soc 2003;125:6650. [PubMed: 12769572]

12. (a) Roush WR, Pinchuk AN, Micalizio GC. Tetrahedron Lett 2000;41:9413. (b) Micalizio GC, Roush WR. Org. Lett 2000;2:461. [PubMed: 10814351]

13. Panek JS, Yang M. J. Am. Chem. Soc 1991;113:9868.

14. Micalizio GC, Roush WR. Org. Lett 2001;3:1949. [PubMed: 11405752]

15. Shotwell JB, Roush WR. Org. Lett 2004;6:3865. [PubMed: 15469369]

16. Tinsley JM, Roush WR. J. Am. Chem. Soc 2005;127:10818. [PubMed: 16076173]

17. Tinsley JM, Mertz E, Chong PY, Rarig R-AF, Roush WR. Org. Lett 2005;7:4245. [PubMed: 16146398]

18. Lambert WT, Roush WR. Org. Lett 2005;7:5501. [PubMed: 16288541]

19. Hoye TR, Wang J. J. Am. Chem. Soc 2005;127:6950. [PubMed: 15884928]

20. Lee E, Tae JS, Lee C, Park CM. Tetrahedron Lett 1993;34:4831.

21. (a) Lee E, Jeong EJ, Kang EJ, Sung LT, Hong SK. J. Am. Chem. Soc 2001;123:10131. [PubMed: 11592906] (b) Jeong EJ, Kang EJ, Sung LT, Hong SK, Lee E. J. Am. Chem. Soc 2002;124:14655. [PubMed: 12465976]

22. Lee E, Choi SJ. Org. Lett 1999;1:1127.

23. Lee E, Yoo S-K, Choo H, Song HY. Tetrahedron Lett 1998;39:317.

24. Lee E, Yoo S-K, Cho Y-S, Cheon H-S, Chong YH. Tetrahedron Lett 1997;38:7757.

25. (a) Pommier A, Pons J-M. Synthesis 1995:729. (b) Wang Y, Tennyson RL, Romo D. Heterocycles 2004;64:605.For selected recent examples, see(a) Donohoe TJ, Sintim HO, Sisangia L, Harling JD. Angew. Chem. Int. Ed 2004;43:2293. (c) Getzle YDYL, Kundnani V, Lobkovsky EB, Coates GW. J. Am. Chem. Soc 2004;126:6842. [PubMed: 15174834] (d) Calter MA, Tretyak OA, Flaschenriem C. Org. Lett 2005;7:1809. [PubMed: 15844912] (e) Mitchell TA, Romo D. Heterocycles 2005;66:627. (f) Shen X, Wasmuth AS, Zhao J, Zhu C, Nelson SG. J. Am. Chem. Soc 2006;128:7438. [PubMed: 16756287] (g) Henry-Riyad H, Lee C, Purohit VC, Romo D. Org. Lett 2006;8:4363. [PubMed: 16956227] (i) Reddy LR, Corey E. J. Org. Lett 2006;8:1717.

26. Lowe C, Vederas JC. Org. Prep. Proced. Int 1995;27:305.

27. (a) Yang HW, Zhao C, Romo D. Tetrahedron 1997;53:16471. (b) Ma G, Zancanella M, Oyola Y, Richardson RD, Smith JW, Romo D. Org. Lett 2006;8:4497. [PubMed: 16986934] (c) Schmitz WD, Messerschmidt B, Romo D. J. Org. Chem 1998;63:2058. (d) Wang Y, Romo D. Org. Lett 2002;4:3231. [PubMed: 12227756]

28. Wang Y, Zhao C, Romo D. Org. Lett 1999;1:1197.

29. Yang HW, Romo D. J. Org. Chem 1997;62:4. [PubMed: 11671357]

30. Mead KT, Pillai SK. Tetrahedron Lett 1993;34:6997.

31. See Supporting Information for details

32. Evans DA, Dart MJ, Duffy JL, Yang MG. J. Am. Chem. Soc 1996;118:4322.

33. ZhaoCPh. D. Thesis1999Texas A\&M University 


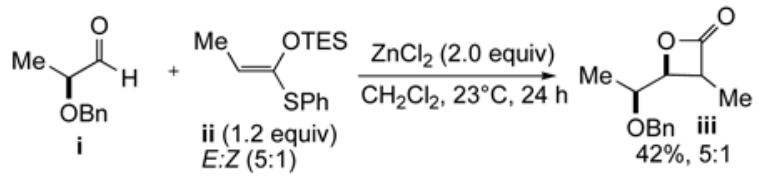

34. Abraham RJ. J. Chem. Soc. B 1968:173.

35. Analysis of molecular models for these $\gamma$-benzyloxy- $\beta$-lactones suggests that there should be a conformational preference due to unfavorable gauche interactions and cancellation of dipoles

36. White D, Zemribo R, Mead KT. Tetrahedron Lett 1997;38:2223.

37. In the course of the total synthesis of (-)-azaspiracid, a similar by-product was observedEvans DA, Kvaerno L, Mulder JA, Raymer B, Dunn TB, Beauchemin A, Olhava E, Juhl M, Kagechika K. Angew. Chem. Int. Ed 2007;46:4693.Similar furans were obtained from the corresponding dihydrofuransKatagiri N, Tabei N, Atsuumi S, Haneda T, Kato T. Chem. Pharm. Bull 1985;33:102.

38. Larsen CH, Ridgway BH, Shaw JT, Woerpel KA. J. Am. Chem. Soc 1999;121:12208. (b) Larsen CH, Ridgway BH, Shaw JT, Smith DM, Woerpel KA. J. Am. Chem. Soc 2005;127:10879. [PubMed: 16076193]

39. Ayala L, Lucero CG, Romero JAC, Tabacco SA, Woerpel KA. J. Am. Chem. Soc 2003;125:15521. [PubMed: 14664599]

40. (a) Keck GE, Boden EP. Tetrahedron Lett 1984;25:265. (b) Kahn SD, Keck GE, Henre W. J. Tetrahedron Lett 1987;28:279. (c) Keck GE, Castellino S. Tetrahedron Lett 1987;28:281. (d) Shambayati S, Blake J, Wierschke SG, Jorgensen WL, Schreiber SL. J. Am. Chem. Soc 1990;112:697. 


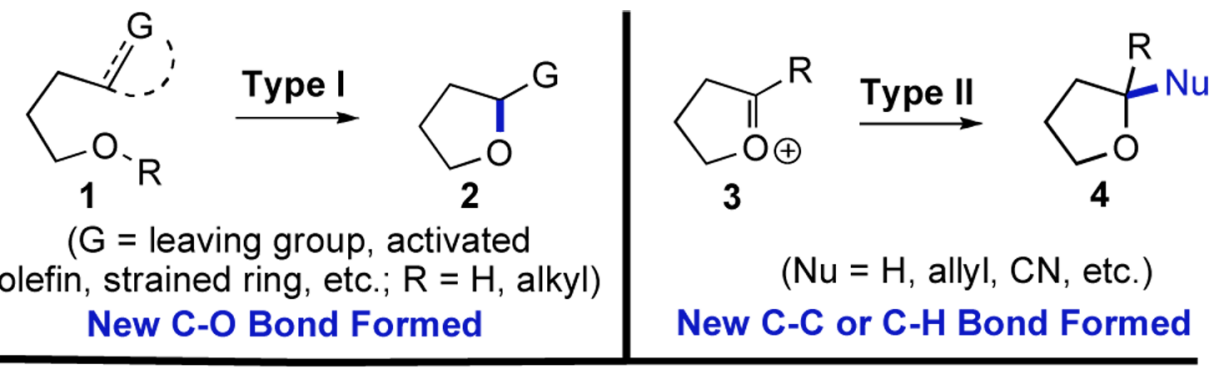

Type III - Misc. (ring contractions, etc.)

Figure 1.

General Routes to Tetrahydrofurans 


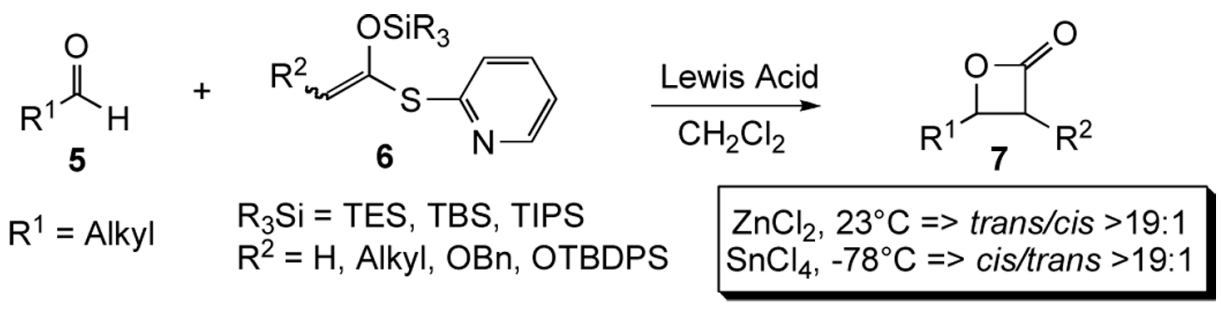

SCHEME 1.

Tandem Mukaiyama Aldol-Lactonization (TMAL) Process 


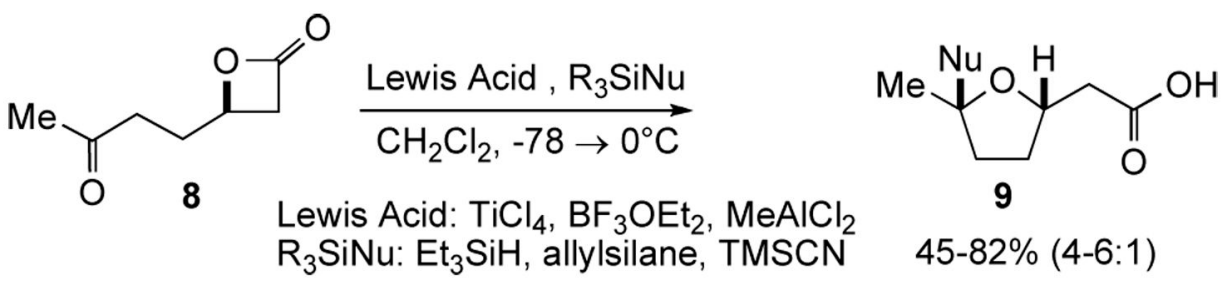

SCHEME 2.

Mead Reductive Cyclization to Tetrahydrofurans 

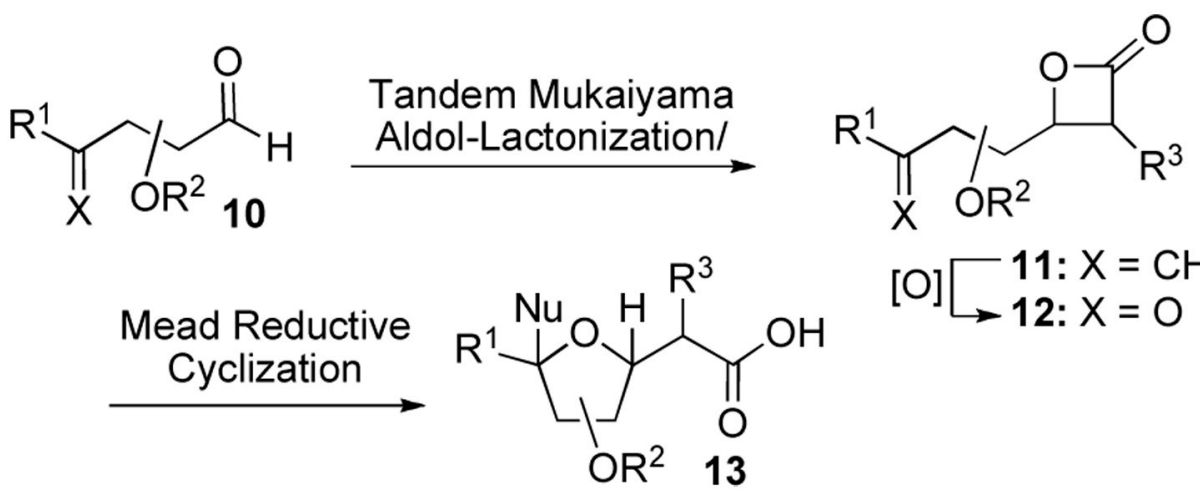

$[\mathrm{O}] \longrightarrow$ 11: $\mathrm{X}=\mathrm{CH}_{2}$

SCHEME 3.

Three-step Strategy Toward Tetrahydrofurans 
<smiles>C=C(C)CC(OCc1ccccc1)C(=O)O[Na]</smiles><smiles>C=C(C)C(=O)[CH+]CC(C)=O</smiles>

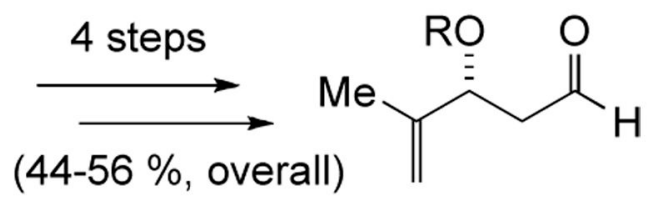

(土)-10b: $R=$ TBS $( \pm)-10 c: R=$ TIPS

SCHEME 4.

Synthesis of Aldehydes ( \pm )-10a-c 

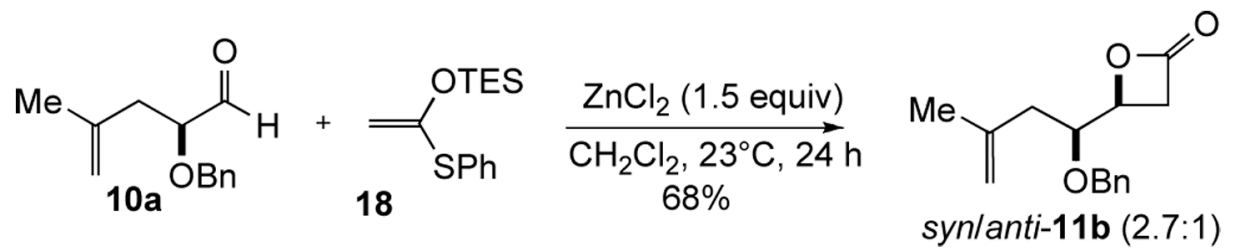

SCHEME 5.

Reversal of Relative Stereochemistry of Alkenyl- $\beta$-Lactone 11b via the TMAL Process with Thiophenyl Ketene Acetal 18 
<smiles>[R]C(O)CC1OC(=O)C1[R]</smiles>

i) $\mathrm{O}_{3}, \mathrm{CH}_{2} \mathrm{Cl}_{2}$<smiles>[R]OCCC1OC(=O)C1[R]</smiles>

SCHEME 6.

Synthesis of Keto- $\beta$-Lactones 12a-f via Ozonolysis 


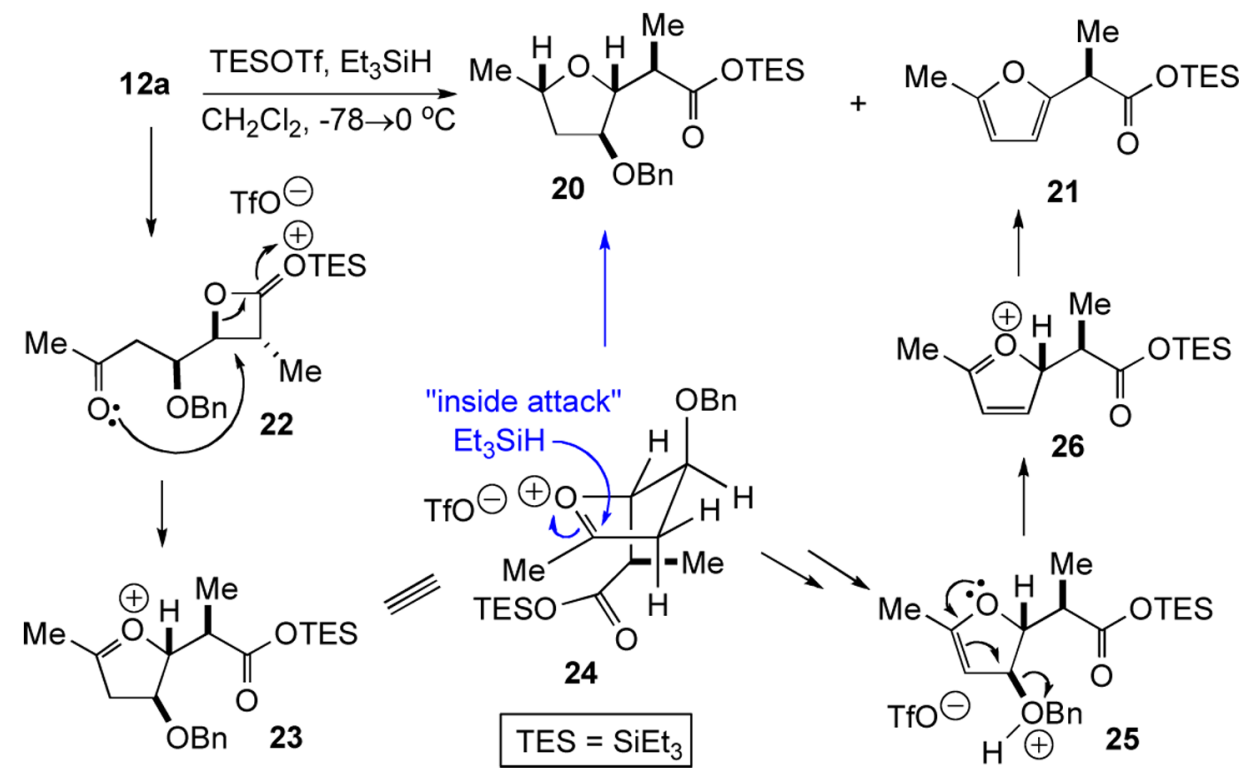

SCHEME 7.

Model for Diastereoselectivity in Reductive Cyclization with $\gamma$-Benzyloxy- $\beta$-Lactones Based on Woerpel's Model and a Proposed Mechanism for Formation of Furan 21 


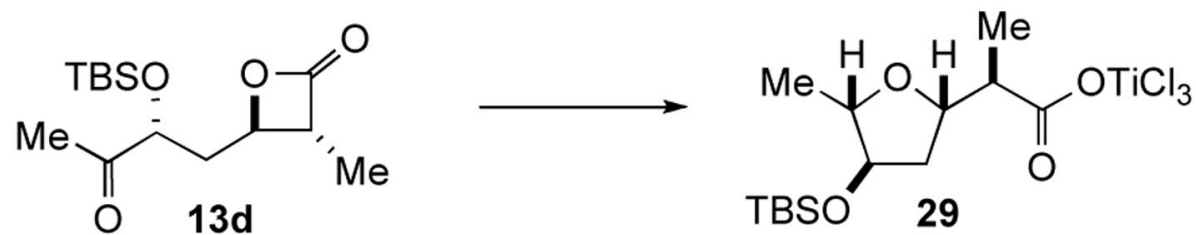

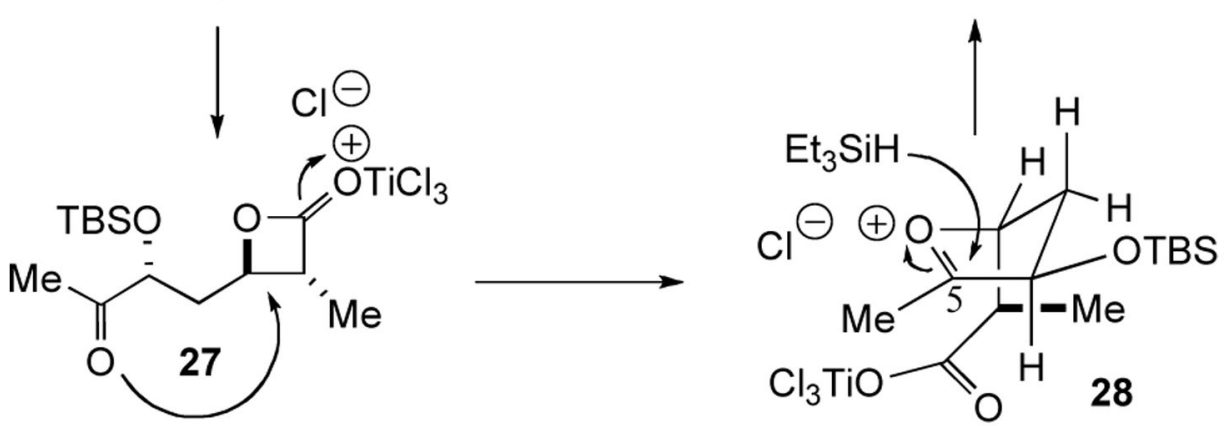

SCHEME 8.

Model for Diastereoselectivity in Reductive Cyclization with $\delta$-Silyloxy- $\beta$-lactones based on Woerpel's Model. 


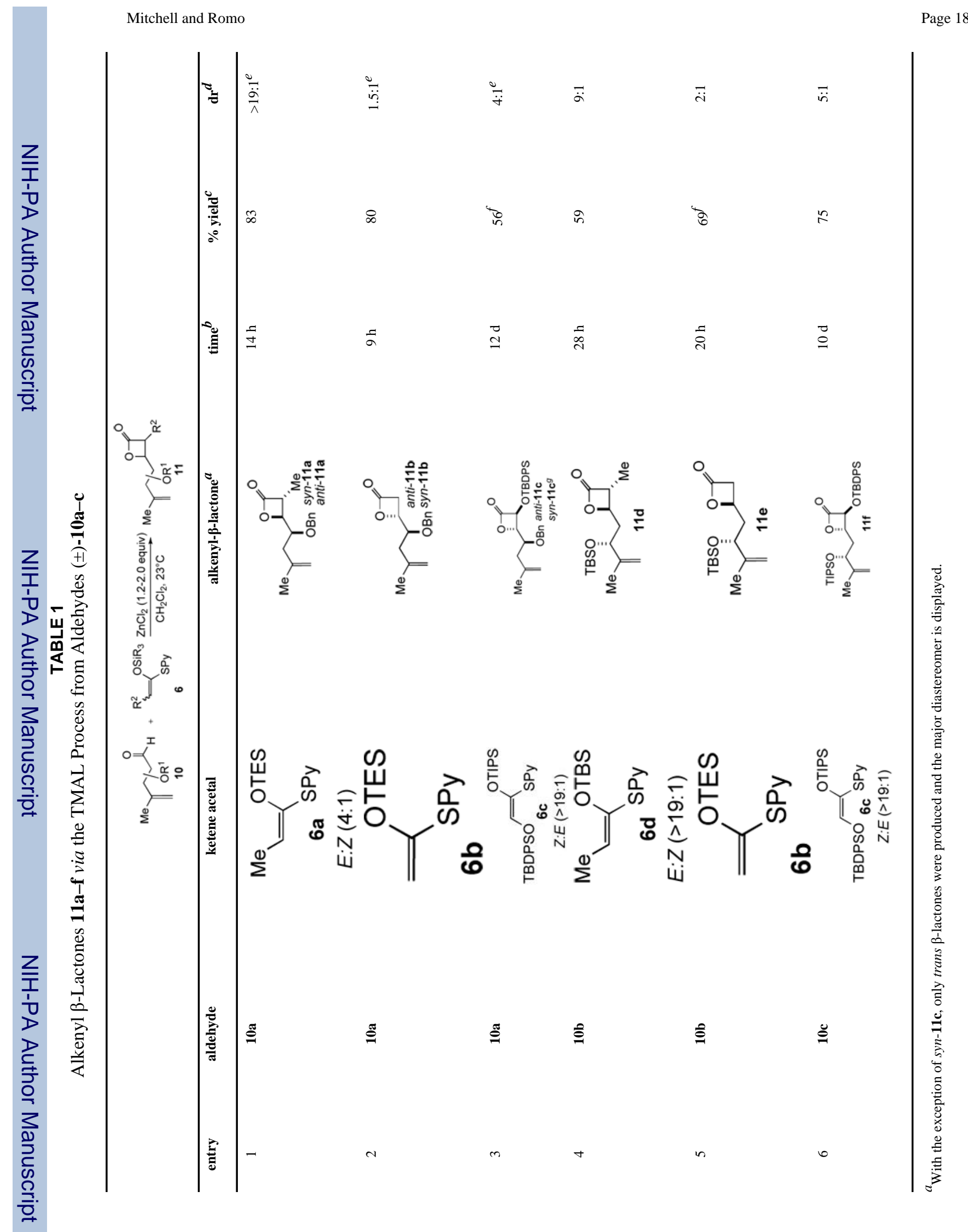

J Org Chem. Author manuscript; available in PMC 2008 December 8. 


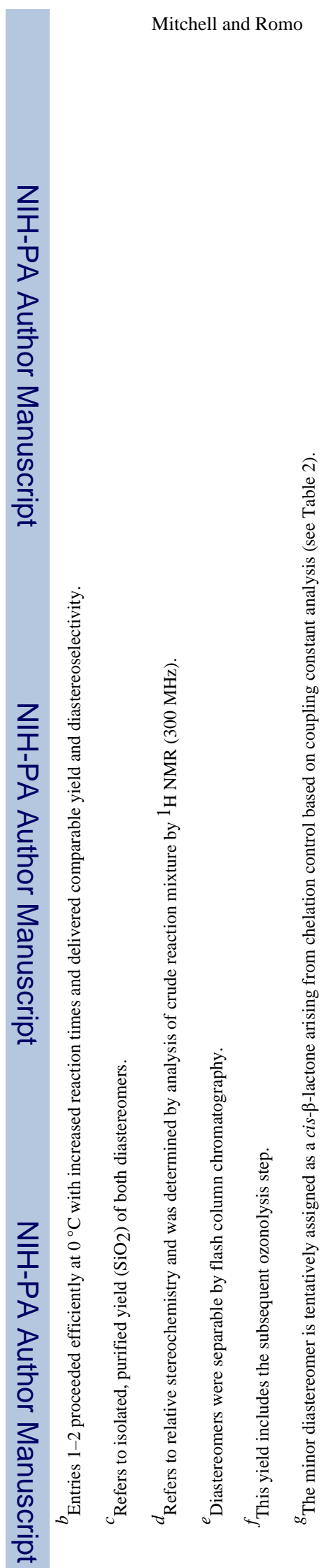

J Org Chem. Author manuscript; available in PMC 2008 December 8. 


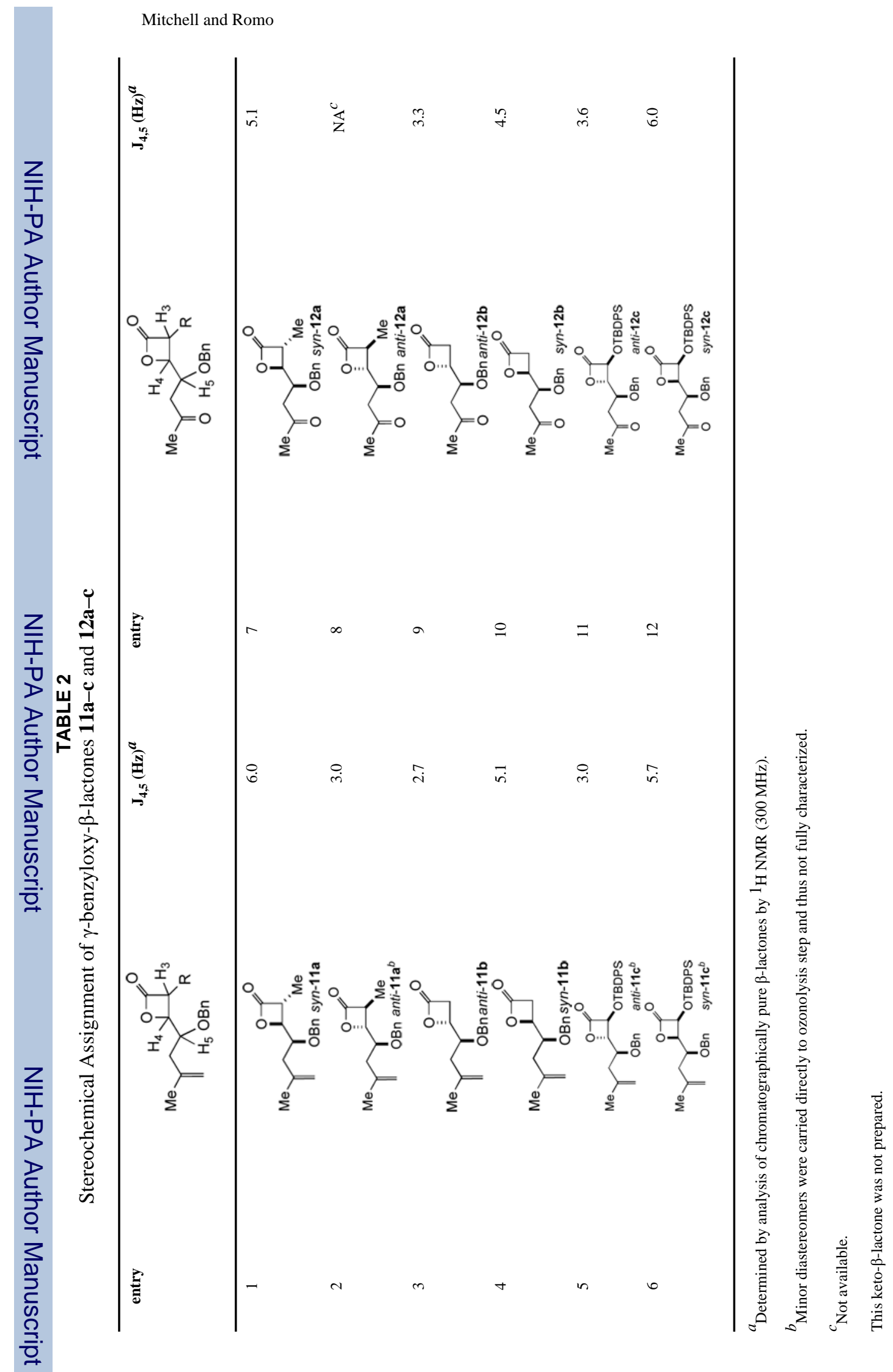

J Org Chem. Author manuscript; available in PMC 2008 December 8. 


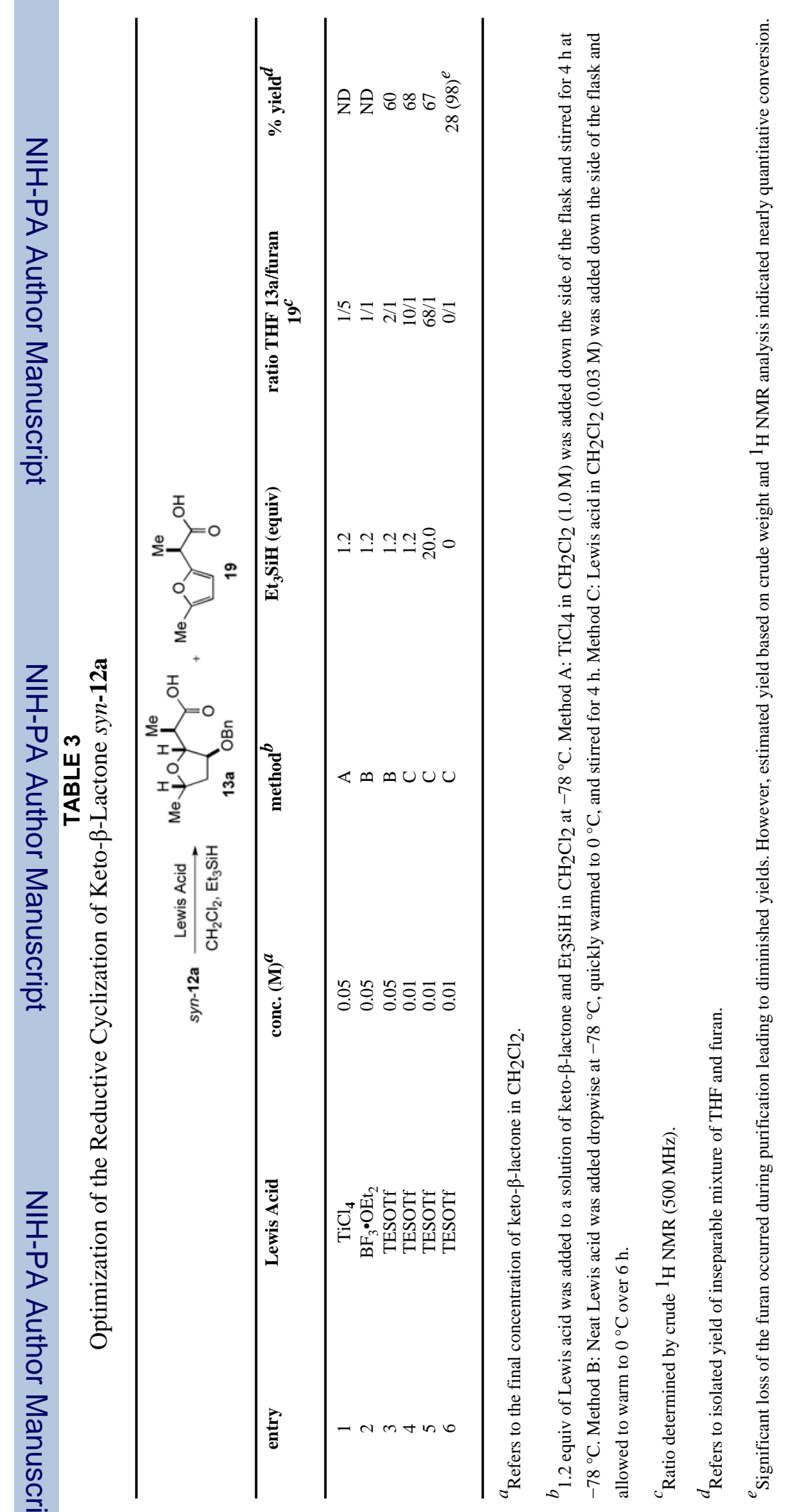




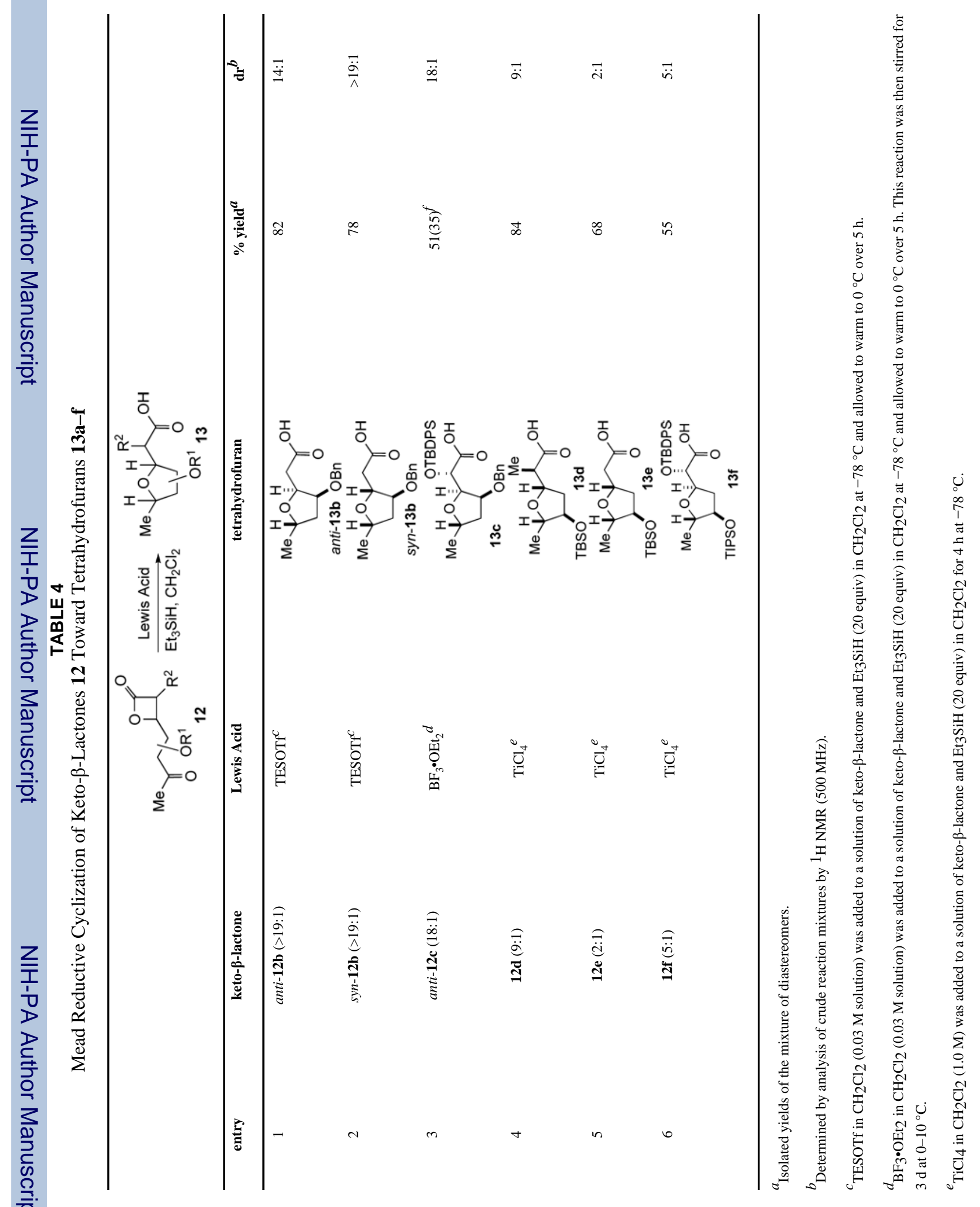


